\title{
Analysis of Factors Causing Poor Passing Rates and High Dropout Rates among Primary School Girls in Malawi
}

\author{
Maureen Kapute Mzuza ${ }^{1, *}$, Yang Yudong ${ }^{2} \&$ Fanuel Kapute $^{3}$ \\ ${ }^{1}$ East China Normal University, Shanghai, China \\ ${ }^{2}$ Shanghai Academy of Educational Sciences, 21 North Cha Ling Road, 200032, Shanghai, China \\ ${ }^{3}$ Mzuzu University, P/Bag 201, Luwinga, Mzuzu 2, Malawi \\ *Corresponding author: East China Normal University, Shanghai, China. E-mail: maureenkapute@yahoo.com
}

Received: December 16, 2013 Accepted: January 29, $2014 \quad$ Online Published: February 11, 2014

doi:10.5430/wje.v4n1p48

URL: http://dx.doi.org/10.5430/wje.v4n1p48

\begin{abstract}
Factors that cause poor examination passing rates and high dropout rates among primary school girls in Malawi were analysed. First hand data was collected by conducting a survey in all the three regions of Malawi. The respondents to the questionnaire were girls (402) who are repeating the last class in primary schools (Standard 8), primary school teachers (481) and Head teachers (82). Secondary data sourced from the Malawi Ministry of Education and the Malawi National Examinations Board (MANEB) was also analysed to validate the survey results. The perception by most primary school girls was that they do not perform well in their examinations due to lack of interest (30.2\%). However, only a handful of Head teachers and teachers considered this as a problem (7\%) suggesting that learners and teachers perceive problems in education differently. There was a strong relationship $(\mathrm{P}<0.05)$ between poor examination passing rates and dropout rates confirming that girls who fail exams eventually lose interest to continue with school but quit and opt to marry also due to over-age. This study concludes that factors affecting the girl-child education in Malawi are multi-dimensional hence need a multi-sectoral approach to solve. It is recommended that government need to critically examine problems facing the girl-child and institute relevant policies to avoid future implications.
\end{abstract}

Keywords: primary school, passing rate, dropout rate, girls

\section{Introduction}

Malawi (Figure 1), a small land locked country situated in the south-eastern part of the African continent is among the poorest nations of the world (World Bank, 2014). According to the Population Reference Bureau (2011), about 91\% of the population live on less than 2 dollars a day. 


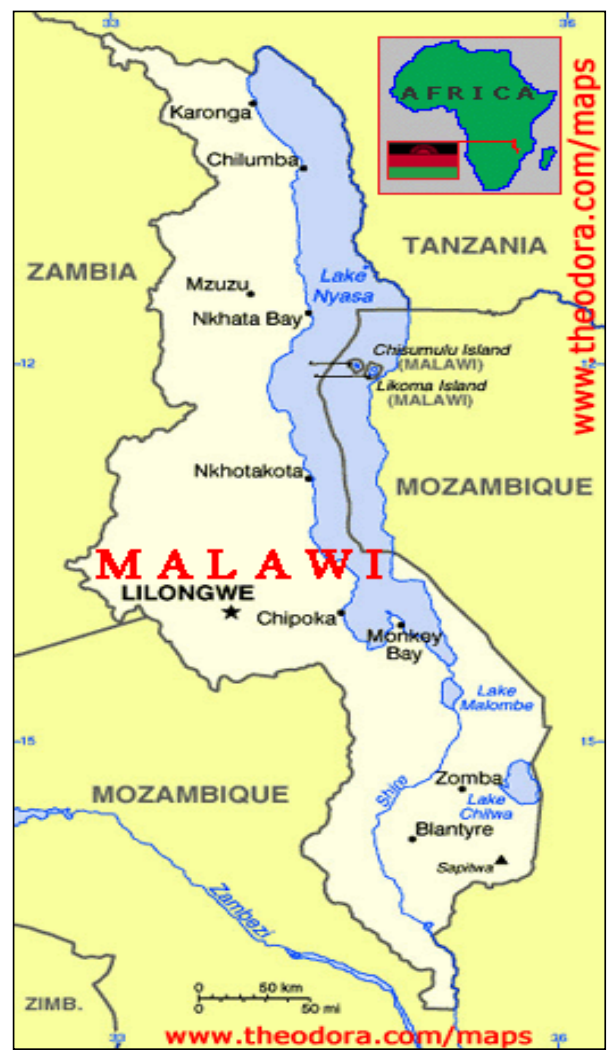

Figure 1. Political Map of Malawi Showing Its Neighbouring Countries

\section{Source: www.theodora.com/maps}

In Malawi, education is one of the most important sectors often ranked second from agriculture. In fact, schooling is considered to be one of the most important levers for increasing the populations living conditions in Malawi. The educational system in Malawi is categorized into three main divisions namely, primary schools, secondary schools and tertiary. Primary school runs from Standard 1 to 8 (eight years). The official entry age into primary school level of education is 6 years though variations appear (Kadzamira \& Rose, 2001). Students write final exams in primary school in Standard eight to qualify for entry into secondary school. Primary education is therefore the most important of the education system in Malawi because it forms the foundation for knowledge gain into secondary and eventually university education. However, illiteracy levels in Malawi are higher among women and also most girls perform poorer than boys and eventually drop out of school. It is reported that only $67.3 \%$ of women is literate versus $76.5 \%$ for men (World Bank Report, 2010). In fact, Malawi is ranked as one of the countries in the southern Africa region with the highest girl drop-out rates among girls (Milner et al., 2001).

Another notable change in the primary school in Malawi is the tremendous increase in students' enrolment from 1994 following introduction of the free primary education by the government (Milner et al. 2001). Consequences of this included shortage of teachers and teaching/learning resources in primary schools.

This study was carried out to establish if the increased enrolment of students into Primary Schools in Malawi has indeed affected the examination passing rate in standard eight of primary schools in Malawi with a focus on girls; determine reasons for poor examination passing rates among girls compared to boys and also to determine reasons for high dropout rates amongst girls in primary schools in Malawi.

\section{Materials and Methods}

\subsection{Research Design}

A structured questionnaire was administered to 42 Head teachers, 481 teachers, and 402 girl students (those repeating Standard 8) from selected primary schools in all 3 regions (southern, central and northern) of Malawi in January 2013 (Table 1). The questionnaire was structured in such a way that it would help in soliciting from respondents (teachers, 
Head teachers and girls repeating standard eight) reasons why most girls in Malawi do not perform well in their standard eight examinations and also why eventually most of these girls drop out from school.

To quantify and validate findings from the questionnaire, secondary data e.g. on students' enrolment, number of teachers, examination pass rate etc were also collected from the Malawi National Examinations Board (MANEB) and the Ministry of Education in Malawi.

Table 1. Structure Dimension and Target Population for Survey

\begin{tabular}{|c|c|c|c|c|}
\hline \multirow{3}{*}{\multicolumn{2}{|c|}{ Dimension }} & \multicolumn{3}{|c|}{ Target population } \\
\hline & & $\begin{array}{c}\text { Girl students } \\
\text { (402) }\end{array}$ & $\begin{array}{c}\text { Teachers } \\
\text { (481) }\end{array}$ & $\begin{array}{c}\text { Head teachers } \\
\text { (82) }\end{array}$ \\
\hline & & \multicolumn{3}{|c|}{ Number of item(s) in corresponding questionnaire } \\
\hline 1. & Socio-cultural factors & & & \\
\hline a) & General reasons why most girls fail exams & 4 & 3 & 3 \\
\hline b) & Inside school reasons & 16 & 5 & 14 \\
\hline c) & Outside school reasons & 9 & 1 & 9 \\
\hline \multicolumn{5}{|c|}{ 2. Economic factors } \\
\hline a) & Inside school reasons & 1 & 1 & 1 \\
\hline b) & Outside school reasons & 2 & 2 & 2 \\
\hline \multicolumn{5}{|c|}{ 3. Political factors } \\
\hline a) & Outside school reasons & 2 & 2 & 2 \\
\hline \multicolumn{5}{|c|}{ 4. Other factors } \\
\hline a) & General & 4 & 4 & 5 \\
\hline
\end{tabular}

\subsection{Data Analysis}

Data were entered into the computer Microsoft Excel then analysed using SPSS Statistical Package Version 15.0. Regression analysis was carried out to check for correlation between different variables e.g. student enrolment versus examination passing rate. Analysis of variance (ANOVA) was used to compare examination passing rate means among years. Simple T-tests were computed to compare examination passing rates between boys and girls over years. Descriptive graphs were plotted to show trends over years in students' enrolment, examination passing rates etc.

\section{Results}

\subsection{Increased Students Enrolment versus Number of Teachers and Schools}

It was apparent from the secondary data (Figure 2) that indeed the introduction of the free primary education after 1994 resulted into high numbers of students enrolled into primary schools in Malawi. 


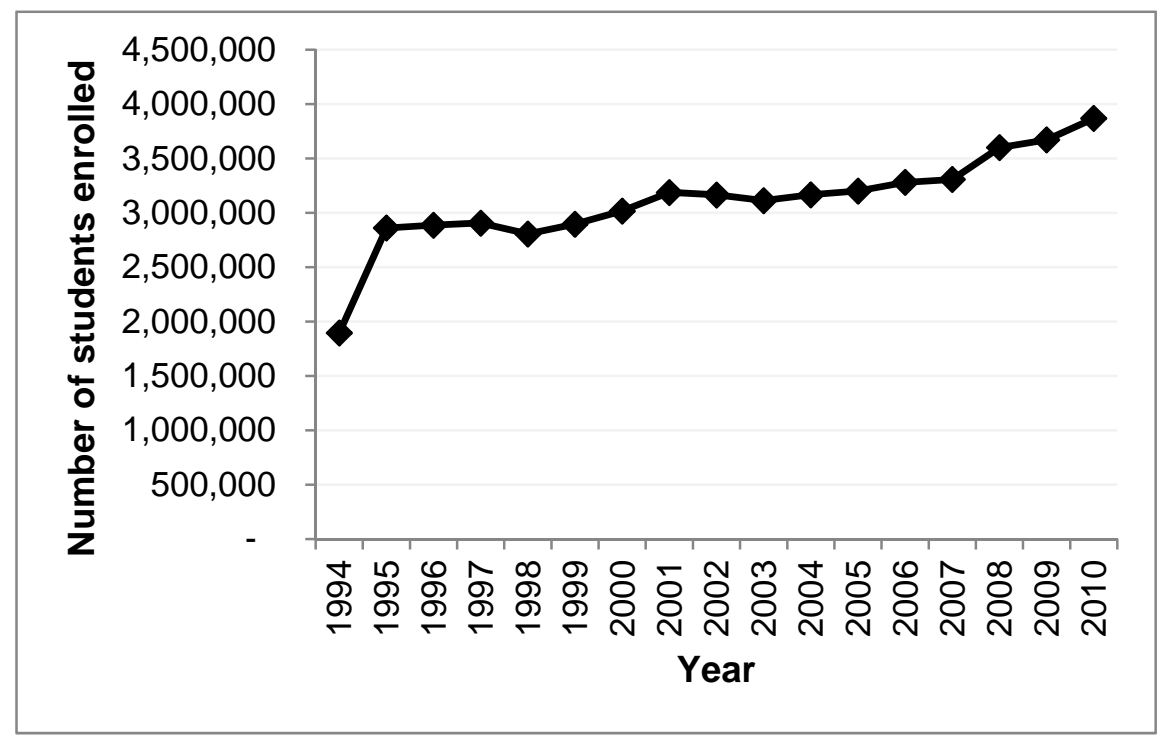

Figure 2. Enrolment of Students into Primary Schools in Malawi between 1994 and 2010

Source: Ministry of Education Basic Education Statistics

It was also clear that the increased number of pupils enrolled into primary schools in Malawi was not accompanied by increased number of teachers and learning class rooms. For example, studies show steadily increasing pupil to class room ratio in primary schools in Malawi (Figure3).

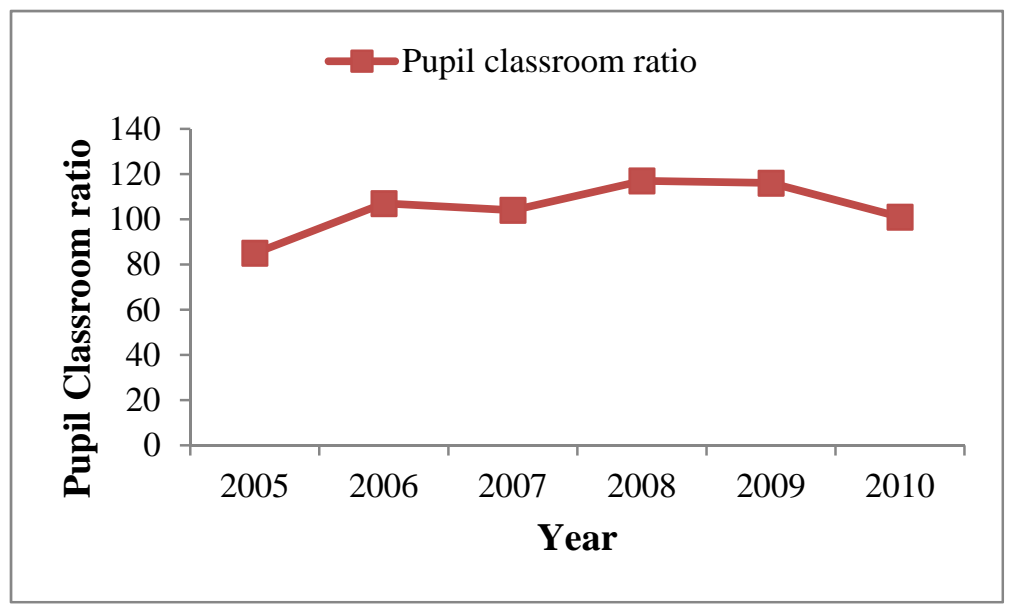

Figure 3. Pupil Class Room Ratio in All Primary Schools from 2005 to 2010

Source: Ministry of Education Basic Education Statistics

\subsection{Examinations Pass Rate between Boys and Girls in Primary Schools in Malawi}

Data from the Malawi National Examinations Board (MANEB) (Figure 4) showed that the examinations pass rate for girls was much lower than that of boys. 


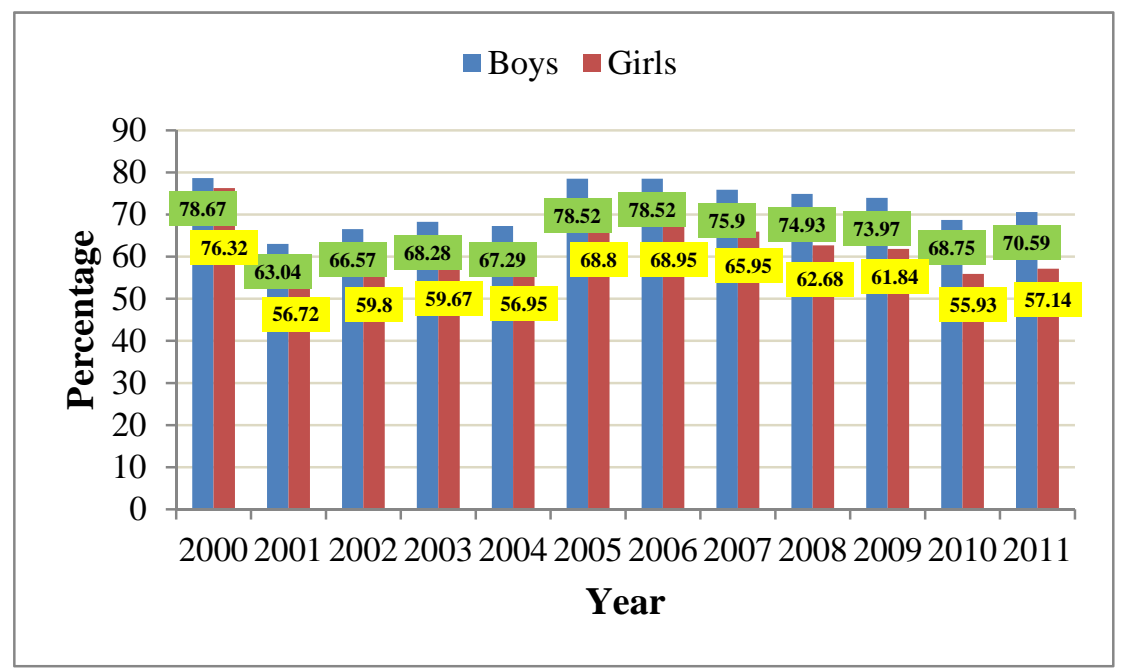

Figure 4. Primary school Leaving Certificate Examinations Pass Rate From 2000-2011

Source: Data kindly provided by the Malawi National Examinations Board (MANEB)

There were statistically significant differences in pass rates between boys and girls in the primary schools in Malawi (Table 2)

Table 2. Analysis of Variance for Pass Rates between Boys and Girls from 2000 to 2011

\begin{tabular}{lrrrrrc}
\hline Source of Variation & \multicolumn{1}{c}{$\boldsymbol{S S}$} & $\boldsymbol{d} \boldsymbol{f}$ & $\boldsymbol{M S}$ & $\boldsymbol{F}$ & $\boldsymbol{P}$-value & $\boldsymbol{F}$ crit. \\
\hline Between Groups & 558.928 & 1 & 558.928 & 23.71088 & $7.23 \mathrm{E}-05$ & 4.300949 \\
Within Groups & 518.598 & 22 & 23.57263 & & & \\
Total & 1077.526 & 23 & & & & \\
\hline
\end{tabular}

\subsection{Drop-out Rates between Boys and Girls in Primary Schools in Malawi}

The number of students enrolled for both boys and girls (but more girls) was generally much higher in Standard 5 but significantly dropped on the way up to Standard 8 (Figure 5).

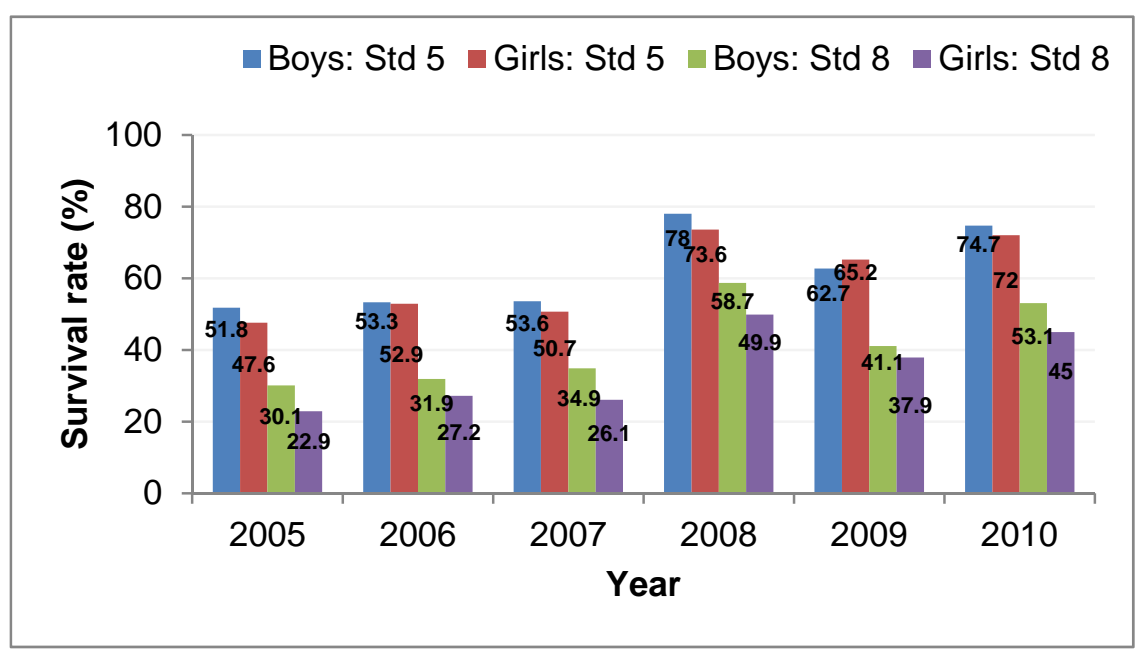

Figure 5. Survival Rate in Standards 5 and 8

Source: Education Statistics, 2010

This suggests that many girls dropped out of school before reaching Standard 8 which is the final class in primary schools in Malawi hence high dropout rates in girls than boys. These results are backed by observations (Figure 6) where more girls repeat classes than boys. 


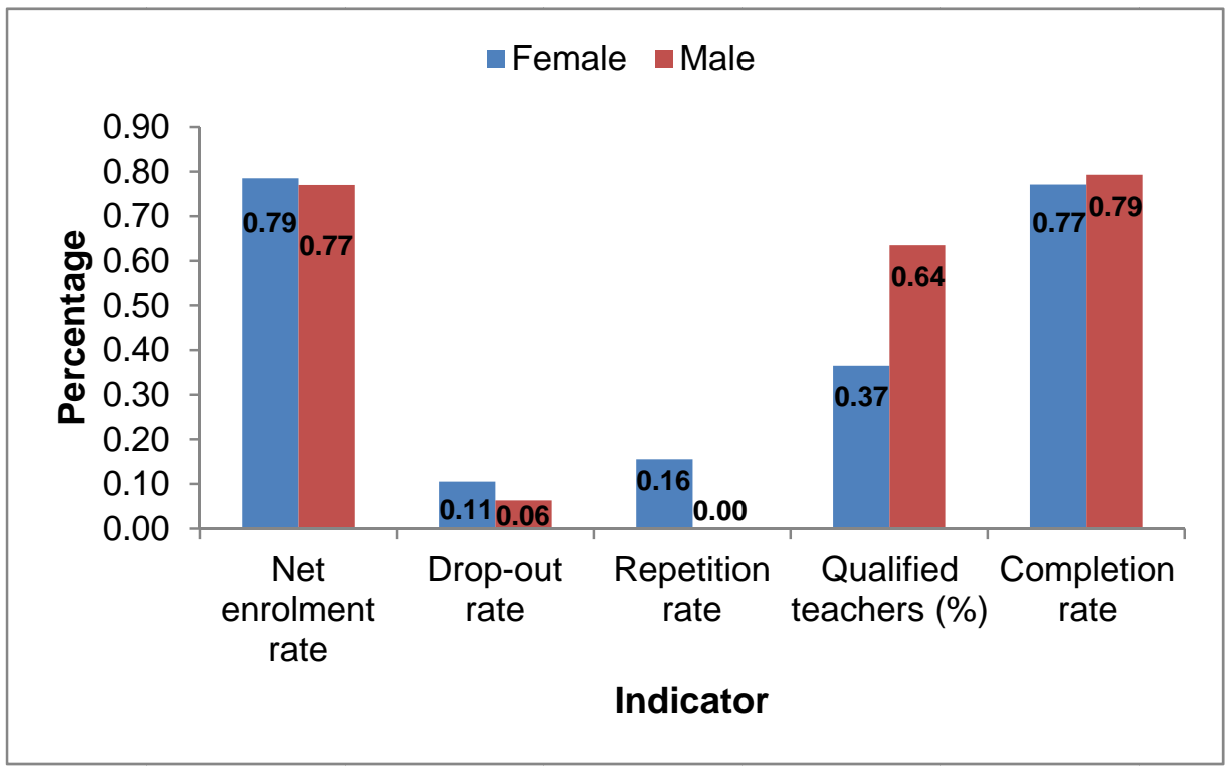

Figure 6. Net Enrolment, Drop-Out Rate, Repetition Rate and Completion Rate

Source: Malawi Ministry of Education

It was worth noting that there were more male qualified teachers than female (Figure 6) which appears to correspond to the high dropout rates in the girls.

3.4 Reasons for Poor Performance in Primary Schools as Reported by Girls repeating Standard Eight of Primary School

Out of 402 repeater girls interviewed (Figure 7), most of them reported lack of interest (30.2\%) as the major reason for their not performing well in their examinations. The other considerable reasons included poverty (16.2\%), lack of learning and teaching materials (10.9\%) such as textbooks, classrooms, desks; and shortage of teachers (8.4\%). Lack of parental care (6.5\%) was also mentioned like in cases where one or both parents are dead or parents are not well educated hence they don't motivate or civic educate and encourage the girls on the importance of education.

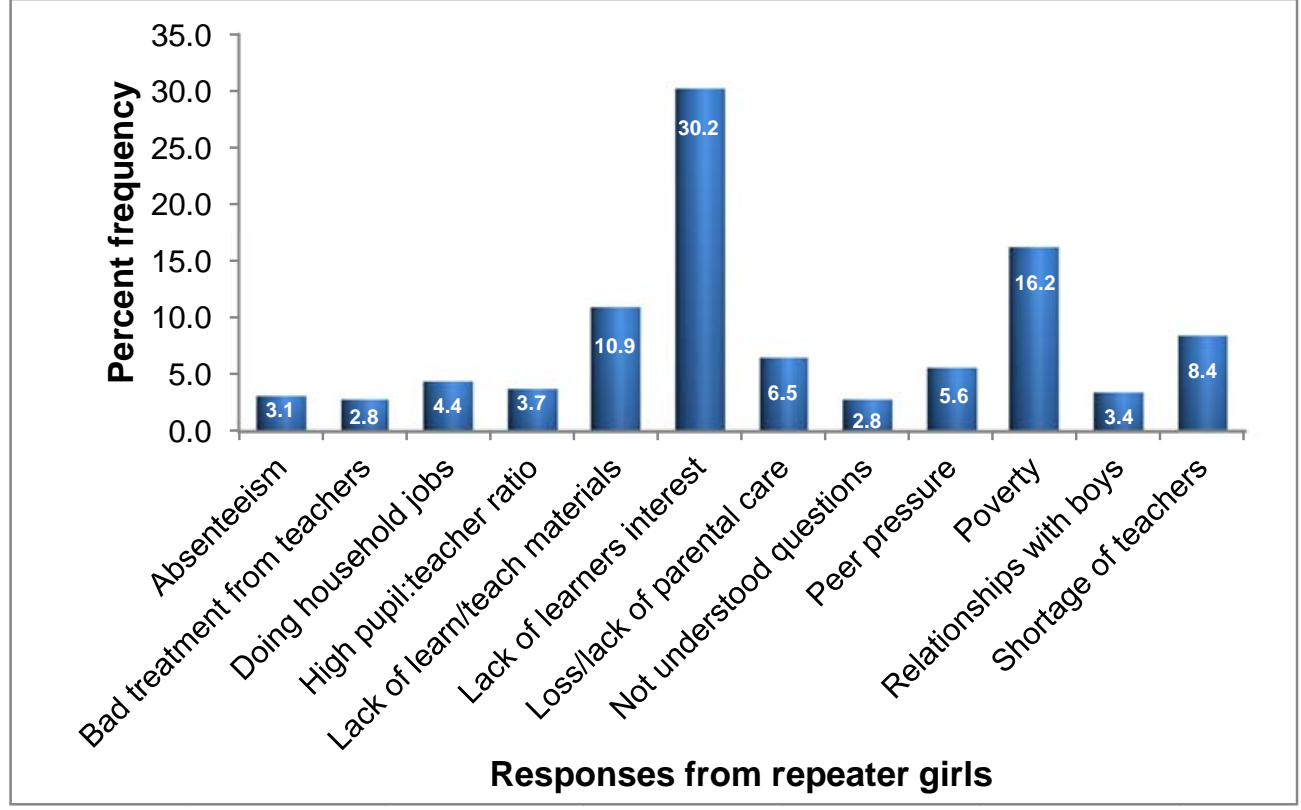

Figure 7. Responses from Repeater Girl to Poor Examination Passing Rates

Other minor reasons included peer pressure (5.6\%), doing household jobs (4.4), high pupil to teacher ratio (3.7\%), relationships with boys (3.4\%) and absenteeism (3.1\%). 


\subsection{Reasons for Poor Performance in Primary Schools as Reported by Teachers}

Out of 481 Primary School Teachers that were interviewed (Figure 8), a majority perceived that lack of teaching and learning materials (18.3\%), lack of motivation due to poor salaries and lack of accommodation (16.2\%), lack of parental support (13.1\%), lack of role models (11.4\%) and early forced marriages and pregnancies (10.5\%) were reasons that consequently caused girls not to perform well in exams.

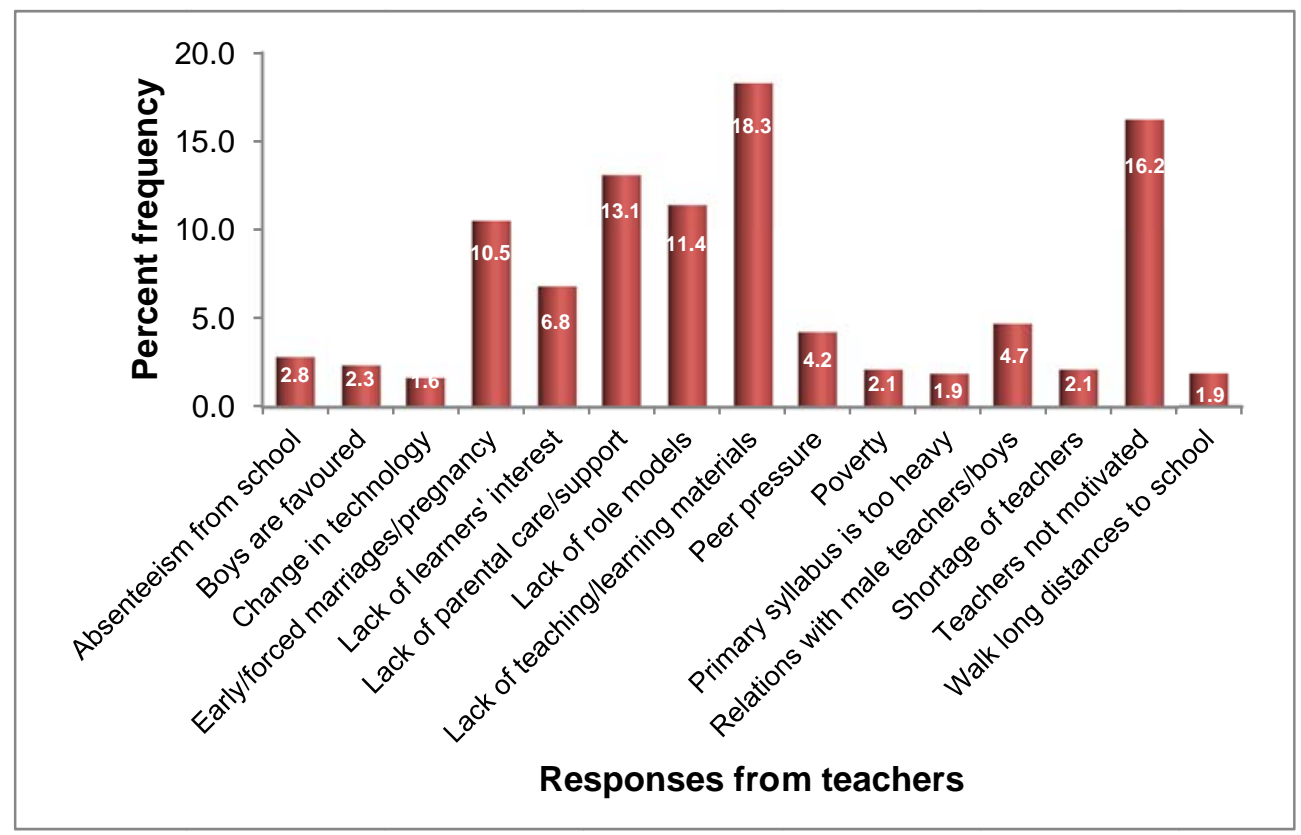

Figure 8. Responses from Teachers to Poor Examination Passing Rates

Other factors included lack of learners' interest (6.8\%); relationships with male teachers and boys (4.7\%) and peer pressure (4.2\%).

\subsection{Reasons for Poor Performance in Primary Schools as Reported by Head Masters}

Out of 42 Head teachers interviewed (Figure 9); many of them (16.7\%) blamed early marriages and pregnancies among girls as the main reason for their poor performance in exams. Lack of parental care and support to girls was another notable reasons mentioned by Head teachers (14.3\%). Lack of role models, peer pressure and poverty (9.5\%) also featured high as reasons for girls' poor results in examinations. 


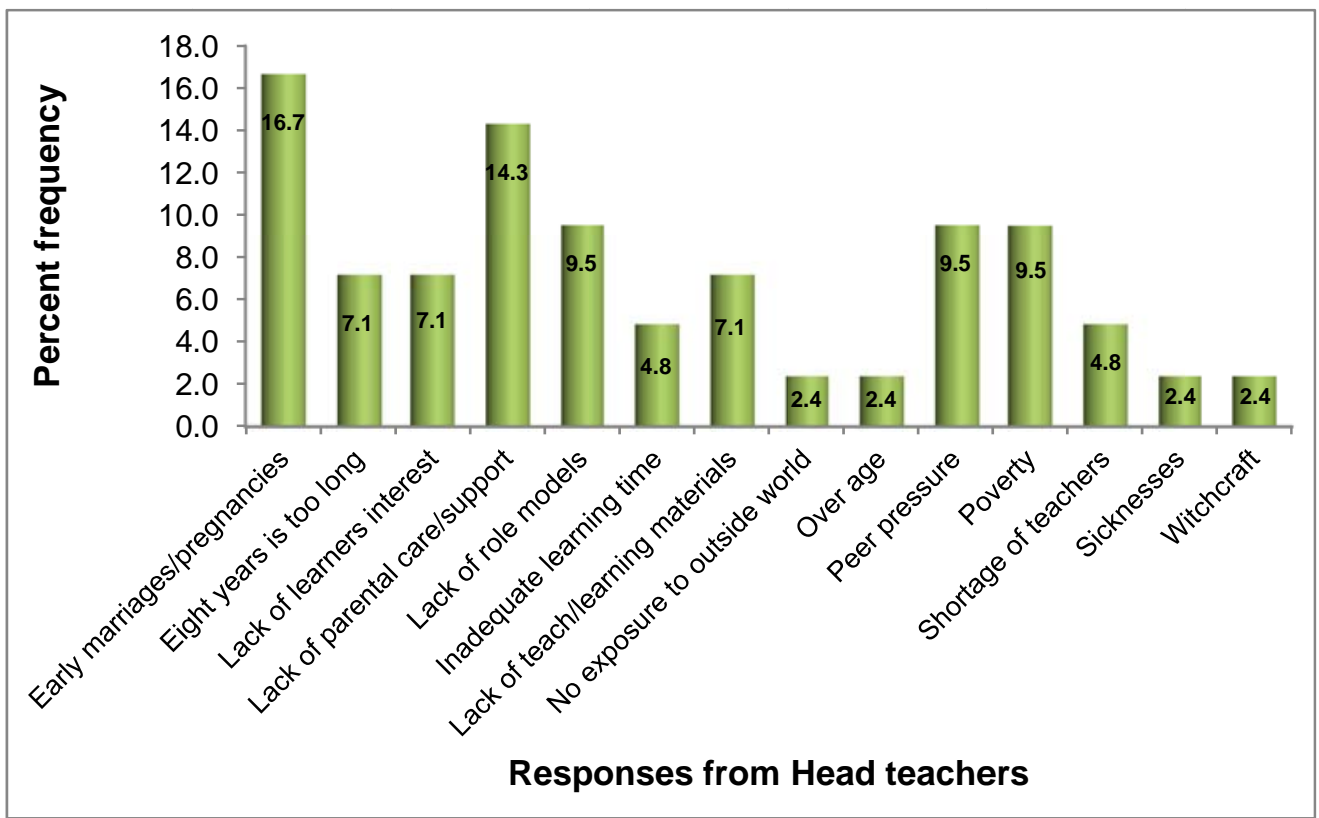

Figure 9. Responses from Head Teachers to Poor Examination Passing Rate

The other reasons included lack of teaching and learning materials, lack of learners' interest and also the concern that eight years of primary school is too long for girls (7.1\%). Shortage of teachers and inadequate learning time were also mentioned as other minor reasons causing poor performance in girls' examination.

\subsection{Summary of Causes To Girls’ Poor Passing Rate from All the Respondents}

After summarising all responses from the girls repeating Standard eight in selected primary schools, their teachers (who also often are involved in the formation and marking of Primary School Leaving Certificate Examinations), and finally the Head teachers in those respective primary schools, major reasons that were mentioned by all respondents were drawn (Figure 10). Four major reasons were isolated as: lack of teaching and learning materials, lack of learners' interest, lack of parental care and poverty and finally peer pressure.

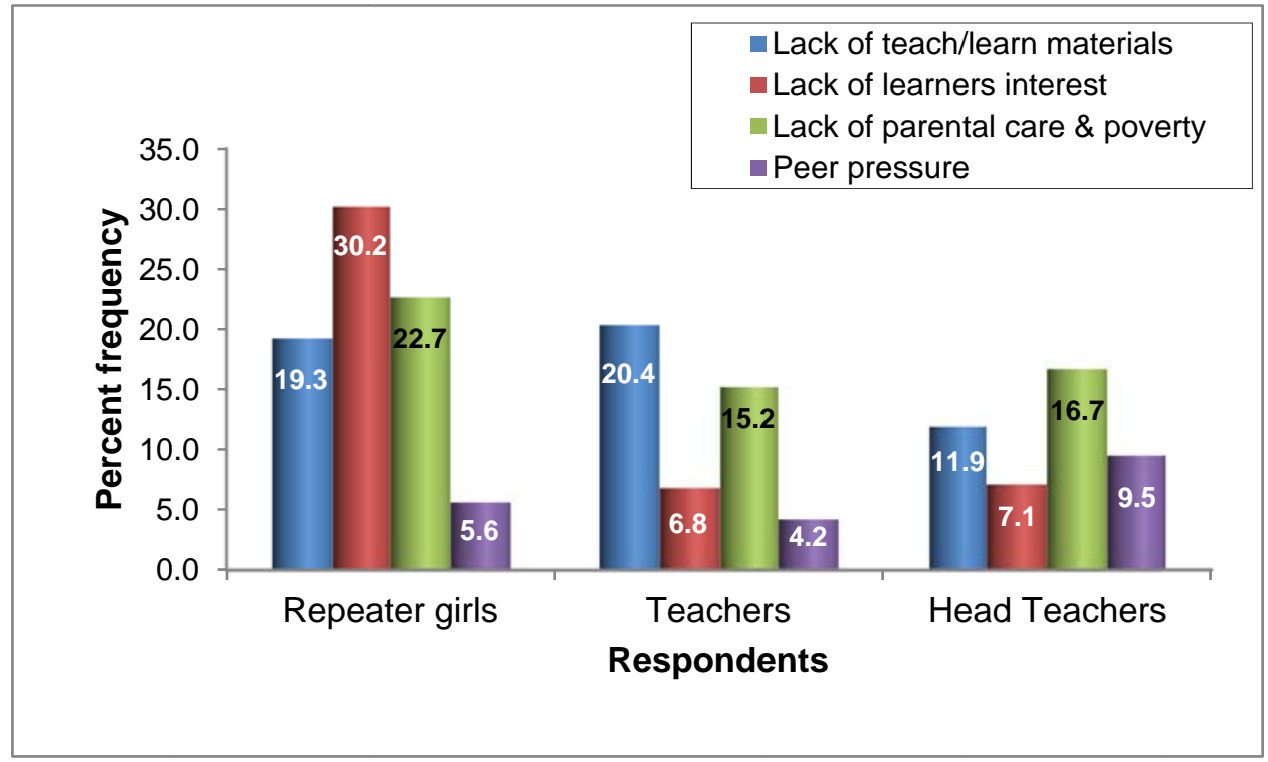

Figure 10. Summary of Responses from Girls, Teachers and Head Teachers

It was apparent that most girls don't perform well in their primary school examinations because they have no interest in pursuing academics (30.2\%) and lack of parental care which in most cases is due to poverty (22.7\%). Girls also highlighted lack of teaching and learning materials amongst their problems. The latter (20.4\%) and lack of parental 
care and poverty (15.2\%) ranked high among teachers while lack of parental care and poverty (16.7\%) and lack of teaching and learning materials $(11.9 \%)$ were highly singled out by most Head teachers as reasons for girls' poor performance in examinations.

However, Head teachers and teachers may likely share similar views regarding performance of girls at primary schools. Responses from head teachers and teachers were therefore averaged and plotted against those from girls. Indeed, it was very striking to observe that while most girls still indicated the problem of lack of learners's interest as the major cause for their poor performance at school, Head teachers and teachers did not consider that as a problem (Figure 11).

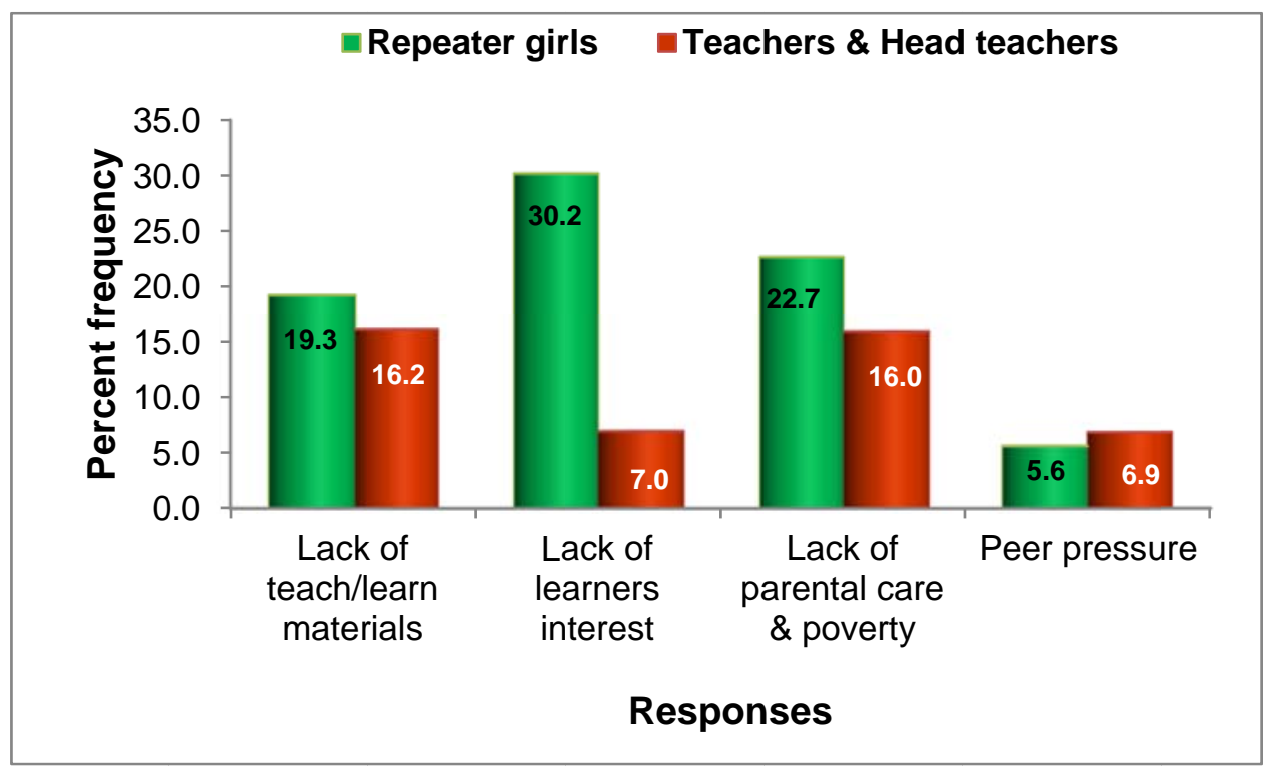

Figure 11. Averaged Responses from Teachers and Head Teachers versus Girls' Responses

This is a clear suggestion that learners' interest is a very important issue that needs to be seriously addressed. However, it appears that both girls and teachers (Head teachers and teachers) agreed that lack of teaching and learning materials is a problem that affects both of them. This means that teachers are not able to deliver their lessons effectively and on the other hand, the students (girls) are not able to concentrate and understand the lessons being taught in class or practicals in the laboratory since there are not enough learning and teaching materials.

\section{Discussion}

\subsection{Increased Pupil Numbers versus Teaching and Learning Resources}

The sharp increase in students' enrolment into primary schools in Malawi after 1994 is a clear indication that indeed financial capacity is one of the major limiting factors to development. In a country where more than $85 \%$ of the population lives in rural areas (FAO, 2011) and over 65\% live below the poverty line i.e. on less than 1 US dollar per day (MPRSP, 2007), many parents in remote rural areas are not able to pay school fees for their children. Removal of fees was therefore a very strong incentive for poor low income parents to send their children to school.

Though the population of Malawi has more females than males (Human Rights Commission, 2005), more boys were enrolled compared to girls despite the primary school be free. This indeed explains many challenges that girls face in Malawi that hinder them from going further with education. It is reported that less number of women attains high education levels than men in Malawi and the SADC region (Sadie, 2005). According to the World Bank, only 27\% of Malawi's girls enroll in secondary school from primary school (World Bank, 2010. http://databank.worldbank.org/ddp/home.do) and just 13\% will attend (Education Statistics, 2010). Further, the increased number of students being enrolled into primary schools in Malawi was not accompanied by equal increase in number of teachers resulting into acute shortage of teachers and learning classrooms. There were highly significant differences between pupil to trained teacher ratio and pass rate of exams in Primary Schools between 2005 and 2009 suggesting that indeed the high pupil to trained teacher ratio has a negative impact on the pass rate of exams in primary school. These are two of the four main indicators of quality of school that were used by the Southern and Eastern Africa Consortium for Monitoring Educational Quality (Milner et al. 2011). Graddy \& Stevens (2005) also reported the high 
pupil to teacher ratio as one of the factors affecting pupil performance even in developed countries such as the United Kingdom.

The observed correlation between the increased enrolment of pupils in primary schools in Malawi and the examination passing rate in standard eight (final grade) agree with studies from other countries (Graddy \& Stevens, 2003). Survey results showed that one of the major causes of poor passing rate was shortage of teaching and learning resources (T/L), which could be due to the increase in students' enrolment. Several studies have attempted to explain the link between the learning environment and performance of the pupils (Wolff, 2010). Though it is argued that resource availability does not correlate with student achievement (Hanushek, 1997), the general observation as reported in this study is that to the contrary, performance of students is directly linked to availability of learning resources also reported by Guloba et al. (2010). Heyneman \& Jamison (1980) observed that shortage of textbooks in Uganda negatively influenced pupil achievement. On the other hand, availability of resources resulted into higher pupil achievement (Graddy \& Stevens, 2005; Greenwald, 1996).

After the introduction of free primary education in 1994, the government of Malawi resorted to a quick way of increasing number of teachers to match the increased pupils' enrolment. This was a departure from the normal two year training program for primary school teachers. Teachers were just recruited and allowed to start teaching without any formal training. The recruitment of unqualified and untrained teachers may also have contributed to the poor performance of pupils during examinations and consequently increased drop outs.

High examination passing rates in Standard 8 of boys than girls may explain why not many girls enrolled into the free primary school in Malawi after 1994, have been successful to reach and pass the primary school leaving certificate examinations that are done in Standard 8 (the final class in primary school).

\subsection{School Dropout amongst Girls in Primary Schools in Malawi}

From $78.5 \%$ of girls who enrolled into primary education in Malawi after introduction of the free primary education compared to boys ( $77 \%$ ), not many of them attended classes normally ( $40 \%$ versus $47 \%$ for boys) and also many girls did not continue with school (dropped out). Many girls also repeated classes ( $15.5 \%$ against only $0.2 \%$ for boys). Probably this may explain why most of them dropped out. It is reported that Malawi has one of the highest school dropout rates in southern Africa, with 15\% of girls (three in every 20 girls), and 12\% of boys ( 3 in every 25 boys), dropping out between Grades 5 and 8 of primary school (Education Statistics, 2010). In Malawi, girls are especially pressured to abandon their education because they have to help out. It was interesting to note girls could get married as early as in Standard 1 and 2 and become pregnant as early as Standard 2 (Table 3).

Table 3. Number of Dropouts by Reasons, Standards and Sex 2009/2010

\begin{tabular}{|c|c|c|c|c|c|c|c|c|c|c|c|c|c|c|c|c|}
\hline \multirow{2}{*}{ REASONS } & \multicolumn{2}{|c|}{ Standard 1} & \multicolumn{2}{|c|}{ Standard 2} & \multicolumn{2}{|c|}{ Standard 3} & \multicolumn{2}{|c|}{ Standard 4} & \multicolumn{2}{|c|}{ Standard 5} & \multicolumn{2}{|c|}{ Standard 6} & \multicolumn{2}{|c|}{ Standard 7} & \multicolumn{2}{|c|}{ Standard 8} \\
\hline & Boys & Girls & Boys & Girls & Boys & Girls & Boys & Girls & Boys & Girls & Boys & Girls & Boys & Girls & Boys & Girls \\
\hline Family jobs & 8656 & 8957 & 5693 & 5770 & 4613 & 4844 & 3415 & 3636 & 2418 & 2442 & 1734 & 1834 & 1416 & 1396 & 1098 & 910 \\
\hline Pregnancy & 0 & 0 & 0 & 1 & 0 & 22 & 2 & 164 & 10 & 552 & 25 & 993 & 47 & 1248 & 66 & 1258 \\
\hline Marriage & 0 & 6 & 0 & 11 & 4 & 149 & 58 & 576 & 185 & 1521 & 258 & 2207 & 468 & 2524 & 598 & 2365 \\
\hline Fees & 180 & 197 & 185 & 145 & 126 & 111 & 133 & 105 & 129 & 115 & 115 & 118 & 117 & 82 & 67 & 67 \\
\hline Employment & 494 & 421 & 665 & 458 & 957 & 771 & 908 & 743 & 830 & 453 & 664 & 360 & 538 & 245 & 384 & 95 \\
\hline Sickness & 1122 & 1057 & 649 & 568 & 410 & 406 & 298 & 323 & 257 & 183 & 148 & 150 & 109 & 102 & 70 & 89 \\
\hline $\begin{array}{l}\text { Poor } \\
\text { Facilities }\end{array}$ & 866 & 906 & 474 & 491 & 365 & 379 & 289 & 279 & 156 & 163 & 144 & 133 & 106 & 95 & 62 & 93 \\
\hline $\begin{array}{l}\text { Teacher } \\
\text { availability }\end{array}$ & 414 & 425 & 287 & 291 & 302 & 314 & 220 & 222 & 151 & 126 & 123 & 120 & 85 & 64 & 59 & 39 \\
\hline $\begin{array}{l}\text { Long } \\
\text { Distances }\end{array}$ & 4172 & 4008 & 1588 & 1770 & 660 & 695 & 379 & 387 & 260 & 233 & 189 & 169 & 129 & 117 & 72 & 40 \\
\hline Violence & 111 & 111 & 68 & 70 & 85 & 70 & 55 & 44 & 31 & 28 & 33 & 19 & 29 & 17 & 23 & 13 \\
\hline
\end{tabular}

Source: Malawi Education Statistics, 2010

This is a confirmation that the issue of early marriage and pregnancy among girls is a serious one.

\subsection{Responses from Girls repeating Standard Eight of Primary School}

Most girls reported lack of personal interest as the major reason for them not performing well in their examinations. Girls could lose interest due to multiple factors such as lack of learning resources which was also mentioned in this study and earlier reported by several authors (Guloba et al., 2010; Graddy \& Stevens, 2005). The problem of over age 
which girls frequently mentioned during the survey including poverty could yet be more convincing reasons for their lack of interest in school. So, while free primary education appears to be "free", the reality is that it is not free because students are required to purchase their own learning resources such as textbooks, school uniform, pens, and notebooks, which many families find difficult also reported by Kadzamira \& Rose (2001) and Al-Samarrai \& Zaman (2000). Also, due to poverty, parents resort to send girls to do piece work such as gardening and doing small business to earn a living. Most girls therefore are absent from school. However, this is not the case for boys. In Malawi, culture also plays a key role in that most parents opt to send boys to school than girls because of the thinking that they will help them in future while girls will be married away. These reasons therefore suggest why rates for drop-outs are high. According to UNESCO, only $58 \%$ of children will complete a full course of primary school, and $20 \%$ of children repeat one or more school years, often several times, if they have had to take significant time out of school and have fallen behind (RIPPLE Africa, 2003-2012).

Though entry age into primary school in Malawi is 6, in rural areas, this is still a small age due to long walking distances to school hence most children start school a little later than 6 years. Also, in view that primary school period is 8 years i.e. from standard 1 to standard 8 , even assuming that children start primary school at the age of 6 , it means that they will be 14 years by the time they reach standard 8. Most girls in Malawi reach puberty after 10 years others as early as 9 years. Therefore, by the time students leave primary school, many of them are far older than primary age, having repeated several years, and many lose interest and drop out altogether. For example, reports from the Malawi Education Statistics (2010) show that some girls marry even while in standard 1 of primary school (Table 3). In fact, the study did not show any case for boys marrying until in standard 4.

In this study, many girls also reported over age and complained about the length of the primary school system (eight years) as reasons for failure at school. Many girls are caught up with age after puberty (12 years or more) and end up getting married or impregnated while at school. After puberty, some parents especially in rural areas force their children to marry. In recent years, this has been influenced by poverty as the parents are not able to take care of their children. With the widespread problems of HIV-Aids, most girls have become victims of looking after their family after loss of parents or nursing sick relatives while boys are allowed to go to school. This may explain why Malawi has high dropout rates in girls than boys.

\subsection{Responses from Teachers}

Majority of teachers perceived that lack of teaching and learning materials, lack of motivation due to poor salaries and lack of accommodation, lack of parental support, lack or role models and early forced marriages and pregnancies were reasons that consequently caused girls not to perform well in exams. These responses appear to be the real situation on the ground in Malawi as far as the education sector is concerned. As mentioned earlier, the lack of interest by the girls is also attributed to lack of parental care especially when they are poor and are unable to support their children with the much needed resources for learning. Probably, every teacher in Malawi will mention lack of motivation from government. Teachers in Malawi are probably the lowest paid civil servants and most of them lack proper accommodation and basic requirements. According to Kruijer (2010) the high numbers of pupils and lack of resources for teaching has created frustration and lack of motivation in teachers to fully discharge their duties. Poor working condition for teachers can affect the quality of education in terms of student examination passing rate (Kruijer, 2010).

\subsection{Responses from Head Teachers}

Most Head teachers observed that most girls fail to go higher with school due to early marriages and pregnancies. Lack of parental care and support to girls were other notable reasons mentioned by Head teachers. Lack of role models, peer pressure and poverty also featured high as reasons for girls' poor results in examinations. While most reasons given by the Head teachers were also noted by teachers and even the girls, it was interesting to see that Head teachers as administrators were able to quickly point out shortage of teachers as yet another cause for girls' problems in passing their exams at school. With the problem of lack of teaching materials such as classrooms, some schools have resorted into having afternoon shifts where one group of students go to school in the morning and the other in the afternoon but the same teachers. Teachers are over worked hence cannot concentrate resulting into poor delivery of the lessons which eventually affect students' performance.

\subsection{Ranking of Causes for Poor Passing Rate in Girls Reported by All Respondents}

Finally, after the four major responses were ranked in order of importance, lack of parental care which probably is aggravated by poverty ranked the highest. The other major responses were lack of teaching and learning materials, lack of learners' interest and finally peer pressure.

It is interesting to observe that parents are perceived to have a great role in helping their girl child to succeed in 
education Involvement of parents in child's early education has been reported to consistently be positive with the child's performance at school (Hill \& Craft, 2003; Marcon, 1999 and Hara \& Burke, 1998). Almost every government funded school in Malawi has serious problems with availability of teaching and learning materials such as textbooks, classrooms, desks, laboratory equipment and chemicals, running water, electricity, toilets, boarding facilities etc. Absence of these makes teaching and learning almost a nightmare as teachers are handicapped. Lack of boarding facilities has become yet another big trap for girls who commute from home and rented houses as they start indulging into different malpractices such as prostitution, drugs etc. As reported by other authors (Graddy \& Stevens, 2005; Greenwald, 1996) this is by far one of the greatest limitations to pupil performance. Lack of learners' interest as discussed already has many causes in itself such as the poor learning environment, lack of learning material, too much work at home such as caring for the sick resulting into absenteeism etc. all result into lack of interest. With increasing technology and modernization, peer pressure among girls is becoming a huge force to watch out. Girls admire super models on internet, magazines etc and strive to become like one of them. Unfortunately, most of these behaviors such as drugs, prostitution etc do not go well together with education. Several authors (Johnson, 2000; Zarina \& Shamsa, 2011) reported Compounded by lack of parental care; most girls get lost into confused and strange behavior and eventually affect their performance in examinations. With age catching up with them, they can no longer go on with school but eventually drop out.

Results in this study demonstrated that girls as young adults and students have completely different views from those of their teachers regarding why they do not perform well at school. Reasons that were reported by girls as most important were actually not considered as issues by the teachers (teachers and Head teachers).

\section{Conclusions}

The study showed that increased number of students being enrolled into primary schools in Malawi was not accompanied by equal increase in number of teachers resulting into acute shortage of teachers for the students. Number of schools was also not increased resulting into shortage of enough learning space. Due to these reasons, teachers could not effectively deliver the teaching material and also on the other hand, students could not concentrate well due to challenges such as lack of teaching and learning materials, congestion in classrooms, and high pupil to teacher ratio etc. Eventually, this affected their pass rate of examinations.

The study also revealed that the eight year period for primary school is long and as a result, most girls are caught up with age. As such, after failing the exams, most of girls resort to getting married or are impregnated hence high drop-out rates.

It was concludes that problems facing and hindering girl child education in Malawi are multi-dimensional and cannot be solved using one method.

\section{Recommendations}

This study recommends that governments (policy makers) should before instituting policies, carefully analyse them in view of future implications. It is recommended that government should continue to deliberately create a more conducive environment for the learning of girls such as building girls' schools. There is also need to have more role women role models that would motivate girls to emulate from and work hard to pass their examinations. There is need for head teachers in schools to encourage team work with teachers. Government should provide all the necessary resources like teaching and learning, continue training more teachers to have more qualified teachers to reduce the teacher pupil ratio and there is also need to continue building more schools to reduce the congestion of students in class. The government should also think of revising the primary school learning period to less than eight years. This would help checking the age problem for the girls as most of them reach puberty during the lower classes in primary school and hence they can hardly continue with education by the time they reach standard eight.

\section{Acknowledgments}

Authors wish to extend their gratitude to the government of the People's Republic of China for sponsoring this study. People in Malawi assisted in collecting primary data. Thanks to the Ministry of Education in Malawi and the Malawi National Examinations Board (MANEB) for kindly providing secondary data. 


\section{References}

Al-Samarrai, S., \& Zaman, H. (2000). Abolishing school fees in Malawi: the impact on education access and equity. Forthcoming in: Education Economics. MPRA Paper No. 130. Retrived from http://mpra.ub.uni-muenchen.de/id/eprint/130

Education Statistics (2010). Education Management Information System (EMIS), 2010. Ministry of Education Science and Technology, Government of Malawi, Lilongwe, Malawi.

FAO (2011). Malawi Country Profile. Gender Inequalities in Rural Employment in Malawi - An Overview. FAO, Rome, Italy. Retrived from www.fao.org/docrep/016/ap092e00.pdf

Graddy, K., \& Stevens, M. (2005). The Impact of School Resources on Student Performance: Study of Private Schools in the United Kingdom. Industrial and Labour Relations Review, 58(3), 435-451.

Graddy, K., \& Stevens, M. (2003). The Impact of School Inputs on Student Performance: An Empirical Study of Private Schools in the United Kingdom. CEPR Discussion Paper No. 3776. Retrieved from http://ssrn.com/abstract=392101

Greenwald, R. (1996). The effect of School Resources of Student Achievement. Review of Educational Research, 66, 361-396. http://dx.doi.org/10.3102/00346543066003361

Guloba, M.M., Wokadala, J., \& Bategeka, L. (2010). Does teaching methods and availability of teaching resources influence pupil's performance: Evidence from our districts in Uganda. Research Series No. 77. Economic Policy Research Centre. Retrieved from http://ageconsearch.umn.edu/bitstream/127537/2/series77.pdf

Hanushek, E.A. (1997). Assessing the effects of school resources on student performance: An update. Educational Evaluation and Policy Analysis, 19(2), 141-164. http://dx.doi.org/10.3102/01623737019002141

Hara, S.R., \& Burke, D.J. (1998). Parent involvement: The key to improved student achievement. The school Community Journal, 8(2), 9-19.

Heyneman, S.P., \& Jamison, D.T. (1980). Student learning in Uganda: Textbook availability and other factors. Comparative Education Review, 24(2), 206-220.

Hill, N.E., \& Craft, S.A. (2003). Parent-school involvement and school performance: Mediated pathways among socioeconomically comparable African American and Euro-American families. Journal of Educational Psychology, 96, 74-83. http://dx.doi.org/10.1037/0022-0663.95.1.74

Human Rights Commission (2005). Cultural Practices and their Impact on the Enjoyment of Human Rights, Particularly the Rights of Women and Children in Malawi. Lilongwe, Malawi. www.medcol.mw/commhealth/publications/cultural_practices_report.pdf

Johnson, K.A. (2000). The peer effect on academic achievement among public elementary students. CDA Report No. 00-06. Heritage Center for Data Analysis, Heritage Foundation, Washington DC. USA. http://thf_media.s3.amazonaws.com

Kadzamira, E., \& Rose, P. (2001). Educational Policy Choice and Policy Practice in Malawi: Dilemma and Disjunctures. IDS Working Paper Series No. 124. Brighton, Institute of Development Studies: 27

Kruijer, H. (2010). Learning how to teach - The upgrading of unqualified primary teachers in sub-Saharan Africa. Lessons from Tanzania, Malawi, and Nigeria. Education International. ISBN 978-92-95089-53-2 (PDF). Printed in Belgium. Download.ei.ie.org/Docs.../ElResearch_Herman_Eng_final_med.pdf

Malawi Poverty Reduction Strategy Paper Annual Progress Report (MPRSP) (2007). International Monetary Fund Country Report No. 05/209. Washington DC, USA. www.imf.org/external/pubs/ft/scr/2007/cr0755.pdf

Marcon, R.A. (1999). Positive relationships between parent school involvement and public school inner-city preschoolers’ development and academic performance. School Psychology Review, 28, 395-412.

Milner, G., Chimombo, J., Banda, T., \& Mchikoma, C. (2001). The quality of primary education in Malawi. An interim Report). Some policy suggestions based on survey of schools. International Institute for Educational Planning/UNESCO, Paris. Retrived from http://www.unesco.org/education/wef/countryreports/malawi/rapport_2.html

Population Reference Bureau (2013). World Population Data Sheet. Washington DC. USA.

RIPPLE Africa (2003-2012). Retrived from www.rippleafrica.org/ 
Sadie, Y. (2005). Women in political decision-making in the SADC region. Agenda, 65, 17-31. http://dx.doi.org/10.1080/10130950.2005.9674616

Wolff, T. (2010). Assessing Student Learning in a Virtual Laboratory Environment. IEEE Transactions on Education, 53(2), 216-222.

World Bank (2010). The education system in Malawi. World Bank Working Paper, No. 182. Washington DC: The International Bank for Reconstruction and Development/The World Bank. http://databank.worldbank.org/ddp/home.do

World Bank (2014). Malawi Overview. Washington DC. www.worldbank.org/en/country/malawi/overview

Zarina, A., \& Shamsa, A. (2011). The effect of peer and parent pressure on the academic achievement of university students. Academic Journal, 11(6), 254. 